\title{
Upper Extremity Part
}

National Cancer Institute

\section{Source}

National Cancer Institute. Upper Extremity Part. NCI Thesaurus. Code C38628.

Any component of the region of the body that includes the arm, the forearm, and hand. 